\title{
Classroom Teachers' Perceptions of Ethical Educational Work
}

\author{
Veera Aijasaho \\ Faculty of Education, University of Lapland \\ Tavintie 8 A 2, 40400 Jyväskylä, Finland
}

Tel. 358-458-957-880Ｅ-mail: veera.aijasaho@gmail.com

\section{Kyösti Vaismaa}

Faculty of Education, University of Lapland

Ylikorvantie 26, 96300 Rovaniemi, Finland

Tel.358-400-663-447Ｅ-mail:kvaismaa@ulapland.fi

\section{Satu Uusiautti}

Faculty of Education, University of Lapland

P.O. Box 122, 96101 Rovaniemi, Finland

Tel. 358-404-844-167Ｅ-mail: satu@uusiautti.fi

\author{
Kaarina Määttä \\ Faculty of Education, University of Lapland \\ P.O. Box 122, 96101 Rovaniemi, Finland \\ Tel. 358-400-696-480Ｅ-mail: Kaarina.Maatta@ulapland.fi
}

Received: Septmeber 4, 2012 Accepted: September 11, 2012 Published: November 1, 2012 doi:10.5296/jse.v2i4.2341 URL: http://dx.doi.org/10.5296/jse.v2i4.2341

\begin{abstract}
Child rearing is one of the fundamental forms of human life: through learning and education, various cultural practices are transmitted from a generation to another. The school
\end{abstract}




\section{Macrothink}

environment can be seen as a moral community from the ethical point of view of education. Teachers are moral actors in this community. But what is ethical educational work in teachers' own opinion? In this study, Finnish classroom teachers' perceptions of ethical education and its nature and significance at school were studied. The purpose was to study teachers' basic values and how they employ them in practice. This was a phenomenographic study and the data were collected through semi-structured theme interviews. The phenomenographic analysis method was applied. Teachers' self-reflection was regarded as the primary tool for developing ethical educational work. Based on the results, a model of the nature of ethical educational practice was created and further discussed. The purpose of this study was to encourage teachers to contemplate and realize education in versatile ways critically reflecting their own values and beliefs and to show the significance of teachers' action at various levels in practical educational work.

Keywords: Educational practice, Classroom teacher, Ethicality, Rearing 


\section{Introduction}

Child rearing is one of the fundamental forms of human life: through learning and education, various cultural practices are transmitted from a generation to another (Rinne, Kivirauma, \& Lehtinen, 2004). Education is fundamentally ethical because it constantly assumes what is good for other people or what is valuable in human life (Putman, 1995; see also Uusiautti \& Määttä, 2012). Kristjan Kristjansson (1998) talks about self-respect as virtue that should be at the core of today's moral education. He describes the post-modern time as a time of missing values and of uncertainty about what is ultimately good and worth pursuing. Robert M. Hutchins (2002) claimed already almost a decade ago that the objective of education is to produce virtue because virtue makes people good and, therefore, makes people happy. His eventual conclusion is that happy people are good citizens. Teaching good and its ethicality in the school world are connected to teachers' action, solutions, the challenges of school world and various expectations set for teachers.

In the Finnish educational system, the goal has always been to raise diligent and good citizens (Paksuniemi \& Määttä, 2011). School is supposed to support rearing that begins and goes on at home. Rearing and education are means to teach children how to act in a right way and to foster their development into ethically aware and sensitive members of the society. An educator's purpose is to enhance children's growth by providing them with conceptual means to reflect their own actions and solve problems. Furthermore, the purpose of the learning relationship is to assist the pupil in developing into an independent and responsible autonomous individual. However, the student does not achieve this goal alone; he or she needs the educator's help and guidance (Pikkarainen, 1994).

Given that there is some common basic assumption of what is good and moral human behavior, it is necessary to discuss how it can be taught children in an ethically sustainable manner. Certainly, children do need guidance, and schools should cultivate students' natural moral sense (Damon, 2010). In addition, Vandenberg (1999) points out that young children may not yet be capable of being ethically responsible for others but that their exchanges with adults are nonetheless ethical because the presence of children calls others to be responsible for their welfare. In school, this responsibility is given to teachers. Therefore, the relationship between a teacher and a student is asymmetrical because the teacher possiesses a quality that the pupil does not (see also Määttä \& Uusiautti, 2011; 2012). The teacher has the opportunity to influence on the child and this position requires ethical reflection.

Indeed, there are a variety of opinions concerning the purpose and realization of values education. In this study, ethical educational work includes features of both moral education and moral practices of school (cf. Jackson, Boostrom, \& Hansen, 1993). In Finland, the teacher's work is guided by various directions and instructions provided by law. Yet, professional ethics is not based on any outer obligation or control. Trade Union of Education in Finland (OAJ, 1998) has named the basic values that lie behind teachers' professional ethics. These values are human dignity, truthfulness, responsibility, and freedom. Tirri (1999) has drawn teachers' values from UN human rights declaration from 1948: In addition to the abovementioned basic values, the principles of teachers' ethical action are also connected to 
the teacher-student relationship, teacher's own personality and action, teacher-colleague interaction, and teacher-society relationship. Likewise, Oser (1991) named rightness and truthfulness as the core dimensions of ethical action but considered responsibility, caring, and engagement salient factors as well. Boyd (1996) states that a moral relationship is conceived primarily in terms of a direct connection between two individuals as a positive ongoing interaction of one caring for the other.

Elizabeth Campbell (2003) adds that in order to be able to act in a true ethical manner, ethical principles should function as a living force in a teacher's consciousness instead of being just some given principles. Whereas Burant, Chubbuck, and Whipp (2007) call for even more carefully formulated ethical codes for teachers: teacher education should provide prospective teachers with ability to evaluate moral situation. Common ethical codes could guarantee natural moral action.

On the other hand, Fallona (2000), for example, distinguishes between four approaches to moral education. The first, value clarification, proposes that teachers use non-indoctrinating and nonjudgmental methods to help pupils discover and refine their values. For the second, cognitive development, teachers function as collaborators, facilitators, and guides, with issues of fairness or morality being analyzed profoundly. The third approach looks at caring that is focused on care for one's self, for intimate others, for associates and acquaintances, for distant others, for nonhuman animals, for plants and the physical environment, for the human-made world of objects and instruments, and for ideas (see also Gilligan, 1982; Noddings, 1988). For the fourth, virtues are considered qualities of a good character, and teachers are responsible for creating a moral community that supports virtues.

Therefore, the school environment can be seen as a moral community from the ethical point of view of education. Teachers, on the other hand, are moral actors in this community. But what is ethical educational work in teachers' own opinion? In this study, classroom teachers' perceptions of ethical education and its nature and significance at school were studied. This question was discussed through four sub-questions:

(1) What kinds of goals teachers set at their educational work?

(2) What are the principles of teachers' ethical educational work?

(3) How do teachers reflect their action as ethical educators?

(4) How does ethical educational work appear in the everyday work according to teachers' perceptions?

The purpose was to study classroom teachers' basic values and how they employ them in practice. Based on the results, a model of the nature of ethical educational practice was created and is further discussed in this article.

\section{Method}

This was a phenomenographic study where the most common data collection method is interview. According to Marton and Booth (1997), there are methodological elements 
associated with phenomenography although it is not a method itself: rather, phenomenography is a way of or an approach to identify, formulate, and tackle certain sorts of research questions. The focus of phenomenographic research is addressing the content of thinking. Phenomenography is interested in the qualitatively different ways people experience, conceptualize, perceive, and understand various aspects of the world around them. People are seen as the bearers of different ways of experiencing various phenomena. (Marton 1988; Niikko, 2003.)

The purpose was to interview classroom teachers about their perceptions of ethical educational practice. The empirical interview data were gathered by the first two authors of the article supervised and guided in various phases of the study by the last two authors. Three criteria were used when selecting the participants: first, they had to work in different places as it was assumed that that could already bring out various perspectives on ethical educational practice; second, teachers with several years of experience were preferred; and third, teachers who were graduated in various periods were preferred. Eventually, six classroom teachers across Finland were interviewed. They had been working as teachers for 8-32 years. When it comes to the third criterion, teachers of various ages were selected and the ones interviewed were aged between 36 and 54 years.

In this study, interviews were semi-structured theme interviews. Themes that retold the abovementioned research questions were discussed with the participants. Relevant additional questions were formulated to be used if necessary. According to Marton (1988), a phenomenographic analysis aims at finding the most essential features of the research phenomenon though a profound interview method that enables the participants to produce meanings through reflective dialogue (see also Niikko, 2003). In this study, four categories were found that represented the classroom teachers' basic values and how they employ them in practice. The data were analyzed through categorization and arranged within carefully defined categories with sub-categories (e.g. Bowden, 2005). These categories included 16 sub-categories that illustrated the participants' relationship with the phenomenon.

Quotations from the interview data were included in the results section to bring out the participants' voices and provide readers with an idea of how the classroom teachers discussed the issues in the interviews. The participants were given fictional names which are placed within brackets after the data excerpts.

\section{Results}

\subsection{The goals of a teacher's educational work}

Various goals set for educational work were emphasized in the teachers' perceptions in this study. The most salient ones were the teaching of humanity and basic life skills, creating an atmosphere, moral education, and the societal importance of educational work. Trust and attention to others were essential themes in all interviews. In addition, many teachers considered teaching co-operative skills important and everyone emphasized the meaning of co-operative and interaction skills in the process of human development. Attention and trust between a teacher and a pupil was highlighted in different connections in most of the 
interviews. Respect for others regardless of situation was regarded as the most central, humane skill.

But it should become automatic so that they know how to apologize without that adult. Because at some point, the adult disappears, perhaps already when 15 years old as the comprehensive school ends and one doesn't necessarily go to school anymore. So the child should be able to act in the world so that the police don't have to take the adult's place and say 'hey, now you've done something wrong and this and this will happen mow'. (William)

The teacher creates the atmosphere in the classroom and one of the goals of educational work is to create a positive atmosphere. Trust is its core element. According to the teachers, in a safe atmosphere, the pupils trust in teacher and the rightness of his or her actions. The teacher self has to build trust in the classroom community because it is not axiomatically present.

But when you know the children and they trust in you, a sort of calm, peaceful, and very safe learning environment can be created. After that the children know when I shrug my shoulders what I think about something. (Brigitte)

Values education is included in various ways in school practices. Good manners, rules, and practices are taught at school and thus, values education is present in quite different situations. Teachers own values inevitably affect teaching and therefore, values education can be discussed from the point of view of teachers' own basic values. Teaching certain values is an important goal of education and a constant part of everyday life at school. The teachers in this study contemplated the appropriate level of teachers' influence on children's values. This is an essential part of ethicality in teachers' work.

How much is a teacher allowed to influence on children's values? I think that, well, common humane values that we pay attention to all and consider everyone equal mo matter who they were. And I think that it's one of the most important things to teachers too that the pupils are equal and they do notice quite quickly that this teacher is fear and just. (Carl)

One of the goals of educational work was to treasure common good and moral individuality and civilization. Here, educational work at school has a significant task and this task cannot be undermined. The teachers interviewed in this study pointed out that the task of school is important not only from the point of view of individuals but also of the whole society:

For the society of course, so that the school would make them such people who would benefit the common good. By working or intellectual values - those are work too. If only they turned into members of the society. (Pearl)

\subsection{The principles of educational work}

According to the interviewees' perceptions, the most fundamental premises of a teacher's educational work are the teacher's basic values, formal framework such as the curriculum, and various norms that direct teachers' work. In addition, educational partnership and the teacher's professional ethic were pointed out. The teachers' own understanding about the most important skills in life set the foundation for the educational work. The teacher's role is to travel by a pupil's side rather directing in the right direction than leading. Likewise, 
openness, honesty, tolerance, and presence were mentioned.

Teachers' own values in teaching and rearing are inevitably shown through their preferences, points of interest, or speaking. They determine how a teacher handles situations at school. As the teacher can act relatively freely, differences between teachers' emphases are clear. On the other hand, solutions in various educational situations are mainly based on the teacher's basic values.

Somehow, I think that the school, teacher and teaching mean provision, providing the skills of acting as a human being... They have proven necessary and perhaps there is a little bit utopist belief in good or something but in my opinion, the goals should be directed in the dream section rather than shrinking the goals beforehand, life surely takes care of it. (Kristen)

Almost all our research participants mentioned the curriculum as a central part of their educational work. The curriculum acts as the justification to the teacher's work, words, or ethical solutions that the teacher has to make. Teachers are state officials and various formal conditions direct and justify their work. A curriculum is a document that every teacher has to know and read carefully. It includes the claims of what must be taught in each school subject but it also directs the educational work and values education at school.

As a state official, the core curriculum guides me... I think that when I'm reading the curriculum, I read it through such lenses that I'll be able to find the legal justifications for my thoughts about how I want to work. (Kristen)

A teacher supports educational work that takes place at home. Parents' values and hopes make an important starting point for teachers' educational work. Inevitably, they direct teachers' solutions. Pupils discuss happenings at home and sometimes teachers may be requested to discuss some issues at school. Honesty and openness toward parents are of primary importance to build trust between the school and home. Educational partnership, at its best, is the best premise of teachers' work in supporting pupils' growthis and development. On the other hand, educational partnership also secures teachers' ethical work. Co-operation with parents provides teachers with opportunities to act and construct teaching as versatile as possible. One of the ethical principles in teachers' work is to treat pupils like they would like their own children to be treated.

When parents learn how to trust in the teacher, they are not afraid that the teacher would misuse his or her power toward their child. A teacher is an adult and quite often the teacher is a mother or father who has own children. And I think that a good advice is that pupils should be treated like I would like to have my children to be treated. (Brigitte)

Professional ethics guides every teacher in their ethical problems and educational situations. It is the foundation for the teacher's ethical action in various solutions that the teacher has to make. In this study, the participants described professional ethics in many ways but they all agreed that pupils should be treated equally. Professional ethics guide teachers in seeing the good and right action in a teacher's profession. As an educator, the teacher is the role model and his or her behavior, solutions, and action must go along with this. In addition, a part of a 
teacher's professional ethics is to do his or her job as well as possible. The profession includes some obligations and rearing is one of them. Moreover, the teacher is obliged to confront each educational situation in a responsible manner.

The teacher's work is ethical. You deal with moral. The understanding about right and wrong and those educational situations are about that. The teacher has to be extremely sensitive, empathic, and listen to the child. And to have time to listen before taking that evaluating viewpoint, because the adult has the power. (Brigitte)

\subsection{Teachers'self-reflection}

In this study, clearly four distinguishable viewpoints were highlighted when it came to the reflection of one's own educational work. The teachers who were interviewed discussed their own action as ethical educators, especially their feelings of inadequacy, experience and inexperience, their own competence as educators, the challenging nature of educational work and values related to educational work.

As they reflected ethicality and their action in educational situations, the importance of experience and inexperience was often highlighted. Newly-graduated teachers were not necessarily prepared for every educational situations and act as a strong ethical actor as more experienced teachers could. Often, inexperience seemed to be related to the feelings of inadequacy whereas a teacher with years of teaching experience may already be stuck to his or her habits and routines. However, teacher education does not provide teachers with ready answers to educational problems. It does provide pedagogical skills and understanding about the profession but the actual learning happens in the field, in real-life situations, through experiences.

As a young teacher after my graduation, I felt that it was like I had just had my driver's license but still had to handle the work. I understood that it was the beginming of my way and that I have to thread my way but the tools I got from the teacher education. Now I just have to use them wisely. So that the ones who graduate as teachers would not be just teachers but wonderers of learning. (Brigitte)

Educational situations were regarded as challenging and every now and then, the teacher's ethical work was considered rather difficult. Working with parents was seen as a challenge of its own - the teacher's profession is not only coping with children but co-operation with many other partners.

It was also noted that the teacher uses his or her personality in teaching. 'Therefore, teachers have to deliberate carefully what they say and do. The teacher cannot act only according to his or her preferences or points of interest but one has to realize one's basic values. Self-reflection is a tool for knowing oneself. Then, it is easier to act in various situations and reflect one's values in educational work and the nature of the teacher's power.

Every teacher is a sort of model and a teacher cannot act just any which way. The teacher must follow the school regulation. And certainly the teacher cannot say aloud his or her opinions at school. The teacher can have his or her freedom of opinion and thinking but as 


\section{Ml Macrothink}

all Finnish children go to school, from quite different families, the teacher has to be quite diplomatic in addition to being a sort of role model. (William)

\subsection{Educational work in practice}

Furthermore, the teachers interviewed in this study discussed how educational work is manifested in practice. The holistic nature of educational situations was emphasized as a part of everyday life at school. In addition, individual educational situations as examples of the nature of educational work were discussed in the interviews. The way the teachers reflected these situations bring out their perceptions of the nature of educational work at school.

The teacher has to have a sort of desire to raise children so that teachers do not just go to school to teach and when something happens they would just yell at children. In my opinion, you educate through you teaching at school and when something happens, you seize the situation and analyze it with children: what happened, why happened, what can be done now, and choose one option and live with it. (William)

Educational conversations are daily routines to a teacher. In conflict situations, it is a challenge to solve situations in an ethically sustainable manner so that the child would understand what he or she did and would not do it again. The teacher has to work intuitively according to his or her best knowledge. In this study, teachers reported various means of analyzing conflicts and knowing when to discuss the present situation with children:

We have this emotional caterpillar that smiles when everything goes well. And then someone can turn its face into a sad face it there is something that worries. But the thing is to have some way of presenting it. And it seems to be really important to these children. (Kristen)

\section{Discussion}

In this study, ethical educational work was analyzed from four perspectives: the goals of educational work, the principles of ethical educational work, teachers' self-reflection, and ethical educational work in practice. The study provided practical information about teachers' own reflection and understanding about their educational work and its moral dimensions. Based on the results, a model of the nature of ethical educational work was created (Figure 1). It highlights the meaning and role of ethicality in teachers' work. The contribution of this illustration is to show how rearing is manifested in practice in schools and what are its goals. Therefore, the everyday educational work and its continuity become easier to understand. 


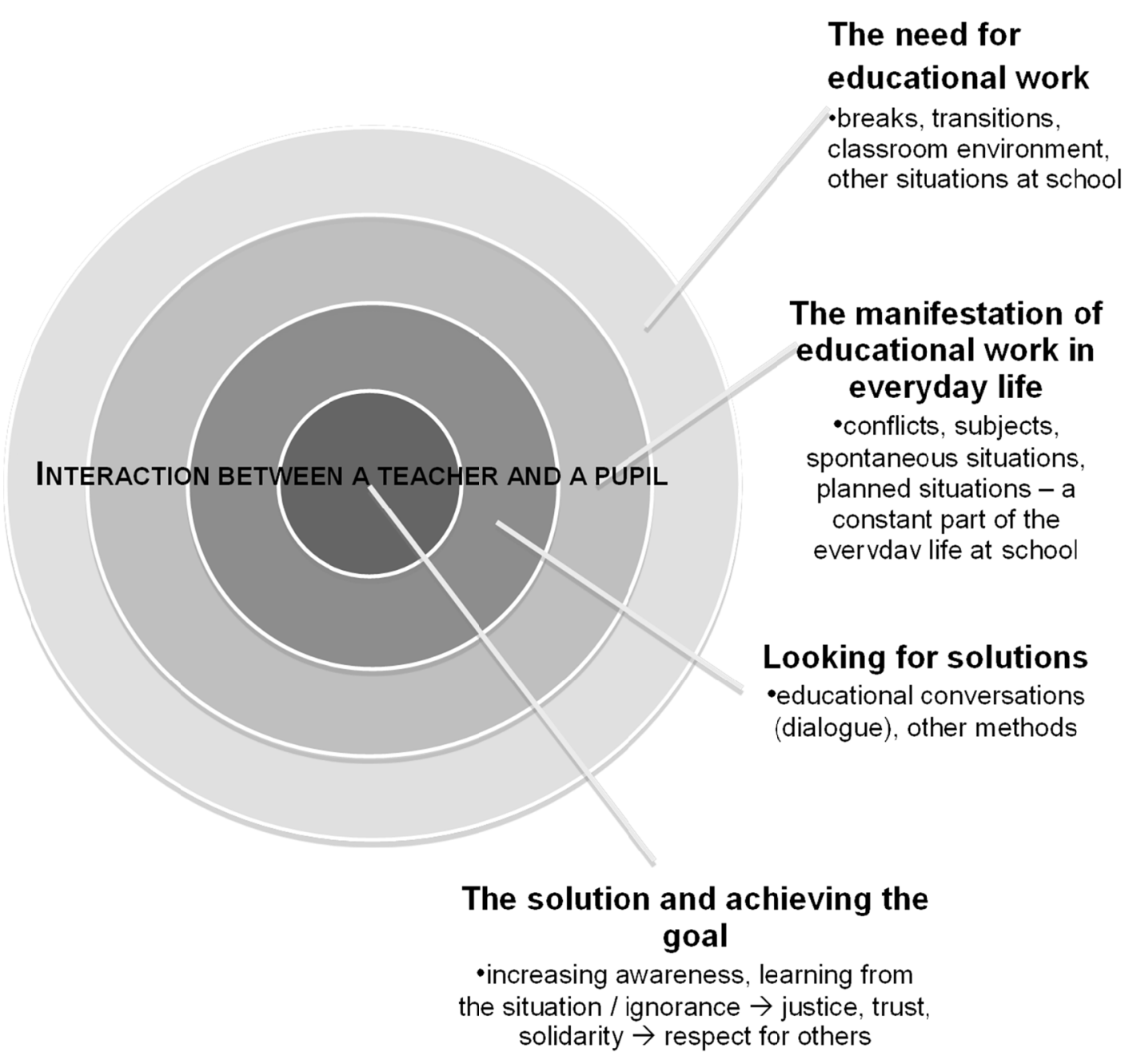

Figure 1. Teachers' perceptions of ethical educational work in the school context.

Educational work is based on interaction between a teacher and a pupil. It is present in each circle and at the core. The model begins from the outmost circle which illustrates the concrete need for education, those direct environments where the need for educational work arises. Such environments are all daily situations at school.

The second circle includes situations where the educational work takes place. A situation that the teacher has planned beforehand can be an educational conversation through which ethical education is included in teaching or various school subjects. Spontaneous situations appear in the form of unstructured educational conversations. They can originate in various subjects, conflicts during breaks, or other needs that pupils may have.

The third circle includes the process of looking for ethical solutions. The solutions can be found through educational conversations and various other methods. In most situations, the solutions will be achieved and we can move to the core of the model that is the uppermost 
goal of educational work. Sometimes, solutions are only temporary and in such cases, the one being raised has not internalized the educational goal and the situation is likely to happen again. Then, it is necessary to return to the first circle and look for a better solution.

The core of educational work aims at logically stable change that is the most salient goal of ethical educational work. The change is achieved through the increase in awareness. On the one hand, it leads to learning from the situation and other the other hand, it leads to ignorance. The goal is the universal behavioral norms of justice, trust, solidarity, and care for fellow human beings.

\section{Conclusion}

Preparing teachers to teach and reflect on ethical issues begins, at the latest, during teacher education (Hutchins, 2002). Daniel (1998) called for teachers to have ability to develop higher-order thinking skills, meaning that they should be able not only to clarify principles and educational goals but also to analyze them in a critical manner. Teachers should have the capacity to recognize and question the role of a teacher and the existing structures and power relationships. Indeed, according to Boyd and Arnold (2000), very little is known about how teachers think about the aims of education. Yet, the success of education depends on how teachers present their understanding about ethicality. This study contributes to this discussion.

Broström (2006) points out that it is beneficial to distinguish between care, teaching, and upbringing activities because doing so can contribute to the process of understanding and planning the educational process. Broström (2006) employs the concept of tact-full care. Pedagogical tact (van Manen, 1991) refers to the ability to handle relations between theory and practice, to be sensitive and understanding, to take the child's perspective, and to respect the child — and it is also considered the core of pedagogical love (Määttä \& Uusiautti, 2011; 2012).

An important question is whether it is even possible to raise children toward ethicality or is it something innate - or something else? In this study, the teachers highlighted their ability to reflect or be tactful in the abovementioned manner. Likewise, Saevi and Eilifsen (2008, p. 11) note that pedagogy itself is ethical and requires thoughtfulness toward the child. Hence, a special relationship between a teacher and a student is generated. Therefore, teaching is also concerned with the ethics of caring and efforts (Burns \& Rathbone, 2010; Gilligan, 1982; Noddings, 1988). A teacher's ethical caring is that of genuine caring, aspiring to understand students, and making an effort to protect, support, and develop students and it reflects a continuous trust that there is more to a learner than is shown on the outside (Määttä \& Uusiautti, 2011).

In this study, teachers also considered their work as role models one critical dimension of ethical educational work. According to Berkowitz and Grych (1998), modeling means simply learning by observing: adults who express empathy or discuss moral reasoning are also modeling these qualities. Although children do not directly adopt these kinds of behaviors, their beliefs and attitudes about how to treat other people may be shaped by such experiences and observations. Democratic decision making and discussion-in which stake-holders are 
given equal power to enter and participate-are likely to enhance compliance, moral-reasoning development, conscience, self-esteem, and altruism in children (Berkowitz \& Grych, 1998).Warmth and support provide children with a sense that they are important human beings who deserve respectful treatment, while demandingness refers to goal setting and requiring certain behaviors from children.

However, it also appeared obvious that it is not possible to provide teachers with ready solutions because each educational situation at school is different and teachers are personalities. On the one hand, teachers should be prepared to think about the ethical nature and dimensions of their profession instead of ready solutions. On the other hand, teachers' critical self-reflection could be the solution. It necessitates that one analyzes personal and professional beliefs, ethics and action. The most challenging task is to distinguish those values that we hope that are guiding our action from those values that actually do it. (Larrivee 2000; see also Noddings 2005.)

Critical self-reflection appeared as means of looking at one's own work both from inside and outside to make the action visible (see McNiff \& Whitehead, 2005). A teacher reflects his or her basic values and professional maturation (Schön, 1983; Whitehead, 1989) although high-flown promises of professional development through refection have also been criticized and questioned (e.g. Loughran, 2002; Osterman \& Kottkamp, 1993; Smyth, 1992). Either way, ethical educational work is a constant part of everyday life at school. Teachers' perceptions about educational work at school proved that sometimes teaching humanity and life skills becomes more important than the actual formal education. Given this perspective, the discussion of the role of ethical issues should have more space in teacher education. The purpose of this study was to encourage teachers to contemplate and realize education in versatile ways critically reflecting their own values and beliefs and show their significance in practical educational work as well.

\section{References}

Berkowitz, M. W., \& Grych, J. H. (1998). Fostering goodness: teaching parents to facilitate children's moral development. Journal of Moral Education, 27(3), 371-391. http://dx.doi.org/10.1080/0305724980270307

Boyd, D. (1996). A question of adequate aims. Journal of Moral Education, 25(1), 21-29. http://dx.doi.org/10.1080/0305724960250102

Boyd, D., \& Arnold, M. L. (2000). Teachers' beliefs, antiracism and moral education: Problems of intersection. Journal of Moral Education, 29(1), 23-45. http://dx.doi.org/10.1080/030572400102916

Bowden, J. (2005). Reflections on the phenomenographic team research process. In J. Bowden \& P. Green (Eds.), Doing developmental phenomengraphy (pp. 11-31). Melbourne: RMIT university press.

Broström, S. (2006). Care and education: towards a new paradigm in early childhood education. Child Youth Care Forum, 35, 391-409. http://dx.doi.org/10.1007/s10566-006-9024-9 


\section{Macrothink}

Burant, T., Chubbuck, S. \& Whipp, J. (2007). Reclaiming the moral in the dispositions debate. Journal of Teacher Education, 58(5), 397-411. http://dx.doi.org/10.1177/0022487107307949

Burns, D. S., \& Rathbone, N. (2010). The relationship of narrative, virtue education, and an ethic of care in teaching practice. In Education, 16(2). http://ineducation.ca/article/relationship-narrative-virtue-education-and-ethic-care-teaching-p ractice

Campbell, E. (2003). The ethical teacher. Maidenhead: Open University Press.

Damon, W. (2010). The bridge to character. Educational Leadership, 67(5), 36-39.

Daniel, M.-F. (1998). P4C in preservice teacher education: difficulties and success encountered in two research projects. Analytic Teaching, 19(1), 15-28.

Fallona, C. (2000). Manner in teaching: a study in observing and interpretting teachers' moral virtues. Teaching and Teacher Education, 16, 681-695.

Gilligan, C. (1982). In a different voice. Psychological theory and women's development. Cambridge, MA: Harvard University Press.

Hutchins, R. M. (1938/2002). Make it a habit. The Great Ideas Online, 182. http://www.thegreatideas.org/95w/tgio182.pdf

Jackson, P., Boostrom, R., \& Hansen, D. (1933). The moral life of schools. San Fransisco, CA: Jossey-Bass Publishers.

Kristjansson, K. (1998). Self-respect, megalopsychia, and moral education. Journal of Moral Education, 27(1), 5-18. http://dx.doi.org/10.1080/0305724980270101

Larrivee, B. (2000). Transforming teaching practice: becoming the critically reflective teacher. Long Beach, CA: California State University.

Loughran, J. J. (2002). Effective reflective practice. In search of meaning in learning about teaching. Journal of Teacher Education, 53(1), 33-43.

Marton, F. (1988). Phenomenography: a research to investigating different understandings of reality. In R. Sherman \& R. B. Webb (Eds.), Qualitative research in education: focus and methods (pp. 141-161). London: Falmer.

Marton, F., \& Booth, S. (1997). Learning and awareness. Mahwah, NJ: Lawrence Erlbaum.

McNiff, J., \&. Whitehead, J. (2005). Action research for teachers. A practical guide. London: David Fulton Publishers.

Määttä, K., \& Uusiautti, S. (2011). Pedagogical love and good teacherhood. In Education, 17(2). http://ineducation.ca/article/pedagogical-love-and-good-teacherhood

Määttä, K., \& Uusiautti, S. (2012). Pedagogical authority and pedagogical love - connected or incompatible? International Journal of Whole Schooling, 8(1), 21-39.

Niikko, A. (2003). Fenomenografia kasvatustieteellisessä tutkimuksessa [Phenomenogrraphy in educational research]. Joensuu: University of Joensuu. 


\section{Macrothink

Noddings, N. (1988). An ethic of caring and its implications for instructional arrangements. American Journal of Education, 96(2), 215-231. http://www.jstor.org/stable/1085252

Noddings, N. (2005). The challenge to care in schools: an alternative approach to education. New York, NY: Teachers College Press.

OAJ. (1998). Puheenvuoroja opettajan ammattietiikasta [Addresses about teachers' professional ethics]. Helsinki: OAJ.

Oser, F. (1991). Professional morality: A discourse approach (the case of the teaching profession). In W. Kurtinez \& J. Gewitz (Eds.), Handbook of moral behaviour and development Volume 2: Research (pp. 191-205). New Jersey, NJ: Lawrence Erlbaum Associates.

Osterman, K. F., \& Kottkamp, R. B. (1993). Reflective practice for educators: improving schooling through professional development. Newbury: Corwin Press.

Paksuniemi, M., \& Määttä, K. (2011). The most decent girls make the best responsible teachers - Teacher selection for teacher education in northern Finland in 1921-1945. Prime Research on Education, 1(1), 10-17.

Putman, D. (1995). The primacy of virtue in children's moral development. Journal of Moral Education, 24(2), 175-184. http://dx.doi.org/10.1080/0305724950240205

Rinne, R., Kivirauma, J., \& Lehtinen, E. (2004). Johdatus kasvatustieteisiin [Introduction to the science of education]. Helsinki: WSOY.

Schön, D. (1983). The reflective practitioner. New York, NY: Basic Books.

Smyth, J. (1992). Teachers' work and the politics of reflection. American Educational Research Journal, 29(2), 267-300. http://dx.doi.org/10.3102/00028312029002268

Tirri, K. (1999). Opettajan ammattietiikka [A teacher's professional ethics]. Helsinki: WSOY.

Vandenberg, B. (1999). Levinas and the ethical context of human development. Human Development, 42, 31-44.

van Manen, M. (1991). The tact of teaching: The meaning of pedagogical thoughtfulness. Albany, NY: State University of New York Press.

Whitehead, J. (1989). Creating a living educational theory from questions of the kind 'How do I improve my practice?' Cambridge Journal of Education, 19(1), 41-52. http://dx.doi.org/10.1080/0305764890190106

\section{Copyright Disclaimer}

Copyright reserved by the author(s).

This article is an open-access article distributed under the terms and conditions of the Creative Commons Attribution license (http://creativecommons.org/licenses/by/3.0/). 